Article

\title{
The Advantages of Industry 4.0 Applications for Sustainability: Results from a Sample of Manufacturing Companies
}

\author{
Riccardo Brozzi ${ }^{1}$, David Forti ${ }^{1,2}$, Erwin Rauch ${ }^{2, *(D)}$ and Dominik T. Matt ${ }^{1,2}$ (D) \\ 1 Fraunhofer Italia Research s.c.a.r.l., A.-Volta-Str. 13/A, 39100 Bolzano, Italy; \\ riccardo.brozzi@fraunhofer.it (R.B.); david.forti@fraunhofer.it or david.forti@natec.unibz.it (D.F.); \\ dominik.matt@fraunhofer.it or dominik.matt@unibz.it (D.T.M.) \\ 2 Industrial Engineering and Automation (IEA), Faculty of Science and Technology, Free University of \\ Bozen-Bolzano, Universitätsplatz 5, 39100 Bolzano, Italy \\ * Correspondence: erwin.rauch@unibz.it; Tel.: +39-0471-017111
}

Received: 30 March 2020; Accepted: 25 April 2020; Published: 1 May 2020

\begin{abstract}
Far from being exclusively related to economic considerations, the advantages of Industry 4.0 applications also include environmental and social concerns. An increasing amount of scientific publications relate the implementation of the fourth industrial revolution paradigm to sustainability. Several studies reported opportunities of Industry 4.0 implementation particularly to the environmental dimension of sustainability, e.g., through improved logistics streams and lowered waste from production. The present research aims at providing evidence on whether manufacturing companies consider Industry 4.0 implementation as an advantage contributing to environmental and social sustainability in terms of lower environmental impact of production, as well as higher physical relief for workers and flexibility of work organisation. The results were an attempt to study such relations with company sizes, industry sectors, turnover and self-assessed levels of digitalization varying. The sample encompasses 65 companies located in the Marche region (Italy). The results show that overall the perception of economic opportunities prevail, while the association of a beneficial impact of Industry 4.0 on environmental sustainability is rather low across companies, regardless of their size, turnover and digital level. As for the statistically significant variables, the results suggest a strong association of the size and the digital level to specific Industry 4.0 related advantages, referring to the social and economic dimension of sustainability, respectively.
\end{abstract}

Keywords: Industry 4.0; SME; sustainability; assessment; field study; small and medium sized enterprises

\section{Introduction}

The core of Industry 4.0 lies in the real-time and smart connection of people, machines and objects for the management of production systems [1]. The introduction of Cyber-Physical Systems (CPS) will enable the digitalisation of the entire value chains, reshaping relations between producers, consumers and suppliers [2]. Consequently, a large scale and heterogeneity of components is emerging also driven by the Key Enabling Technologies (KET) of Industry 4.0, encompassing, among other things, advance manufacturing solutions, additive manufacturing, augmented and virtual reality, simulation, Internet of Things (IoT), cloud, big data and cyber security. Industry 4.0 solutions exhibit an increasing application potential across several businesses and industries. However, the success of Industry 4.0 and the approaches under it will ultimately depend on whether small and medium sized enterprises (SMEs) can adopt and implement these technologies, as they represent the backbone of several productive systems worldwide [3]. The process leading SMEs shifting their production 
and organisational mindsets towards Industry 4.0, as well as the implementation of digital projects, introduces several opportunities and challenges [4-6]. To support digital transformation in SMEs in the last years, several EU countries launched innovation policies. Most of them foresee measures encouraging research and development actions which have been considered to play an important role in the decision to launch investments in digital technologies [7]. The introduction of technologies and concepts inherited from the Industry 4.0 paradigm is considered strategic also for small and medium sized enterprises (SME) to ensure competitiveness, increasing productivity and flexibility of production systems [8,9], while matching the growing market demand for customised products and services [10]. In recent times, business, research and institutions have been increasingly focusing their attention on the sustainability implications of Industry 4.0, in terms of economic, environmental and social impacts of manufacturing and digitalisation, requiring the scientific community to further explore such dynamics [11].

Several scholars agree that Industry 4.0 can provide, beyond economic advantages, numerous opportunities for environmental and social sustainability [12-14]. The expected advantages of Industry 4.0 for sustainability target the overall promotion of sustainable development [15] through the achievement of higher resource efficiency, waste reduction [16] and the realisation of a more favourable production environment for workers, e.g., in terms of higher physical relief and safety $[17,18]$. The consideration of these growing series of aspects calls for shifting the focus of analysis, adopting the Triple Bottom Line (TBL) approach, that is, extending the assessment of relevant factors among companies, for the implementation of Industry 4.0 to the economic, environmental and social dimensions of sustainability [19]. Within the ongoing scientific debate on this topic, notably Müller et al. have acknowledged the importance of understanding the underlying dynamics of the implementation of Industry 4.0, the predominant focus of existing literature on the analysis of technical motivations and the need to adopt differentiated approaches considering, e.g., company size as an explanatory variable to adequately investigate the emerging relations [20]. Beier et al. affirm the lack in research investigating the impact of digitalized industry on the relevance of sustainability aspects [21].

In this work we conduct a study to investigate the benefits of Industry 4.0 applications for sustainability. We use the results from a sample of manufacturing companies, which were asked by means of a questionnaire. In detail, we investigate to what extent manufacturing companies see Industry 4.0 as an advantage for economic, environmental and social sustainability. Furthermore, the study gives an overview of whether there are different opinions depending on turnover or company size. The main findings of our study indicate that the consideration of economic opportunities prevails over environmental and social ones. Environmental opportunities are not considered relevant by companies. The overall perception of the beneficial impact of Industry 4.0 on environmental sustainability is that it is low, and this trend is consistent among companies of different sizes, yearly turnover and digital level. The social opportunity relating to flexible organisation of work emerges as a driver in large companies, more so than SMEs. The economic opportunity, relating to improved logistics, results were strongly implicated for companies with a higher digital level.

The paper is structured as follows. After a short introduction the state of the art regarding the main relations between Industry 4.0 and sustainability will be outlined. The methodology employed to collect data and typologies of the analysis conducted are presented. To test the hypothesis emerging from the literature review indicating Industry 4.0 holding opportunity for realizing sustainable industrial value creation [12,20,22], the present paper derived evidence from the results of a digital self-assessment tool, distributed among a sample of manufacturing companies, encompassing both SMEs and large companies. For this reason, the presentation of results will provide general information on the characteristics of the sample and specific analysis of the subject of this research, namely the existing relations regarding sustainability and Industry 4.0 among the considered groups of responding companies. The results will be discussed considering the scientific publications about the topic included and concrete implications for practitioners and academia. Finally, conclusions will be drawn paving the way for future studies based on the emerging evidence and limits of this research. 


\section{Theoretical Background}

\subsection{Literature Review}

The "Brundtland" report published in 1987 by the World Commission coined the term "sustainable development", giving rise to an increasing societal awareness towards the environmental impact of industrial manufacturing [23]. The emerging environmental concerns such as availability of non-renewable resources and stricter legislation, as well as consumer preference for environmentally friendly products, require manufacturing companies to consider sustainability in their supply chain [24]. From a sustainability perspective, focusing exclusively on the maximisation of profits without considering additional stakeholder concerns is becoming less tolerable [25]. Nevertheless, it is logical to think that the economic profitability of the company is an indispensable element for its existence [26]. The consideration of aspects other than the economic implications of sustainability has the potential to boost innovation and enhance the competitiveness of companies [27]. Against this background, an increasing number of scholars argue that Industry 4.0 holds great opportunity for realizing sustainable industrial value creation on all three dimensions of sustainability: Economic, social and environmental [12].

The terms Industry 4.0 and fourth industrial revolution were used for the first time at the Hannover Fair in 2011, referring to a smart real time connection between people, machines and objects with the aim of managing a production system [1]. Industry 4.0 has been defined as the convergence of Internet technologies in the manufacturing environment [28]. The concept of Industry 4.0 includes several technologies, which are defined as the key enabling technologies of this strategic initiative; these are: Advanced manufacturing solutions, additive manufacturing, augmented and virtual reality, simulation, horizontal and vertical data integration, industrial Internet, cloud computing, cyber security, big data and analytics. Internet of things (IoT) and Cyber Physical Systems (CPS) make it possible to create networks incorporating the entire manufacturing processes converting factories into smart environments in which the physical and the virtual world cooperate [29]. Over the last few years the attention that has been given and the number of conferences and studies dedicated to the topic of Industry 4.0 have grown exponentially [30], not only in the academic environment but also from managers who recognize the potential of this paradigm-shift impacting the entire concept of production, the processes involved as well as the dynamics among suppliers and customers. The fourth industrial revolution has created several opportunities and challenges for SMEs [31,32], which can take advantage of these technologies to increase their flexibility, productivity and competitiveness $[9,28]$.

From a sustainability point of view, Stock and Selinger [12] identified Industry 4.0 as a step towards a more sustainable industrial value creation, arguing that industrial value creation must be geared towards sustainability and Industry 4.0, providing immense opportunities for the realization of sustainable manufacturing. By providing detailed information on each point of the production process, resource and energy use can be optimized over the entire value network [22]. The scientific debate considers the Triple Bottom Line construct [23], consisting of the analysis of environmental, economic and social aspects of sustainability. Authors mentioning such an approach included in their analysis combinations of these dimensions such as environmental [33], economic and social [24] as well as the entire TBL construct [14]. A comprehensive review of the state of the art in terms of environmental and economic aspects reported that research activities are clearly unbalanced and focus mainly on energy as specific input mean [24]. In fact, Morelli [34], relates the use of environmentally responsible and sustainable energy sources and the effort of improving energy efficiency to the concept of sustainability. Vance et al. [35] show that a reduction of energy consumption can be considered as a step towards sustainability. Bonilla et al. [36] provided a systematic overview of scientific publications relating Industry 4.0 to environmental sustainability, drawing conclusions about the uncertainty of the long-run impact of digital transformation on environmental sustainability. The impacts on sustainability have been assessed in relation to specific key enabling technologies on the sustainable value creation of a manufacturing company such as IoT on reshoring. In logistics [12], a reduction 
in the number of transport processes as well as unnecessary material flows can be achieved [22]. Decentralised production, which can be translated into reduced transport distances based on relocating production closer to where products and production equipment are purchased, leads to a decrease in both logistics costs and environmental impact $[5,37]$. This can be achieved with the use of new production technologies such as additive manufacturing that can help to shorten and reduce the size of the value chain [38]. Furthermore, the number of wrong deliveries, unnecessary waiting time and damaged products can be reduced by data transparency throughout the entire supply chain $[39,40]$. In other words technologies associated with the concept of Industry 4.0 are considered to have the unique potential to unlock environmentally sustainable manufacturing [33], and positive relations to environmental sustainability are detected in terms of load balancing optimisation, leading to a reduction in energy consumption [41,42]. Further aspects which are related to environmental sustainability are product usage, waste, end-life products and information [36].

Additional sources relate Industry 4.0 to the concept of sustainability from an ecological point of view and at the same time link it to the social perspective. Since social sustainability is necessary to the fulfilment of the three dimensions of the TBL, it deserves a specific and detailed analysis [43]. The increasing level of automation [44] and collaboration between the workers and the machines [45] will improve people's working conditions. This is particularly advantageous, since the proportion of older workers will increase due to the age shift [22]. It implements collaborative robots into the workstations, which are non-ergonomically designed and physically demanding and preserves workers' health and consequently the productivity of the production system in the long term [18,46]. Smart worker assistance systems will support operators in performing tasks that are monotonous and repetitive, resulting in higher employee satisfaction and motivation [47]. These approaches meet the current demographic challenges since the working environment needs to be designed age-appropriately [28]. These are just examples of the impact Industry 4.0 has on sustainability. From the literature review, it has been shown that even sustainability has a positive impact on the implementation of Industry 4.0, by working as an incentive for the implementation of the related technologies. As Kiel et al. [14] state, the environmental and social opportunities which Industry 4.0 has to offer have a positive impact on the companies' tendency to start the implementation process of Industry 4.0. In this regard, literature identifies sustainability also as the implementation and usage of tools, methods, processes, approaches and practices that aim at improving the company's contribution to sustainable development [48], which is the main focus of the present study.

\subsection{Research Question}

The literature analysis shows numerous advantages of the introduction of technologies and concepts of Industry 4.0 for sustainability. In the literature, however, there is currently a limited number of studies analysing and reporting on the differences between the perceived opportunities of Industry 4.0 implementation on sustainability in larger companies and SMEs. We see here a large gap in scientific research, which should be tackled, increasing targeted research in this field. Therefore, in this paper we focus on the influence of Industry 4.0 on sustainability, adopting a TBL approach, among manufacturing SMEs and large companies. In detail, the present work will answer the research question of whether manufacturing companies perceive the economic, environmental and social sustainability opportunities driven from the implementation of Industry 4.0. More specifically the following research questions (RQ) have been formulated:

RQ1: To what extent do manufacturing companies consider Industry 4.0 as an advantage related to economic, social and environmental sustainability?

RQ2: Which variables might explain differences in the perception of economic, social and environmental sustainability among companies?

To answer these questions, the advantages and challenges related to the implementation of Industry 4.0 technologies and concepts perceived by companies were analysed, considering the 
TBL of sustainability, which covers different aspects such as the economic, environmental and social dimensions $[23,49,50]$. Furthermore, the paper investigated whether specific characteristics of companies, such as size and digital level of the company, are associated with differences in the perception of specific dimensions of sustainability (economic, social or environmental) as an advantage driven by Industry 4.0 implementation. This approach is aligned to the study of Müller et al., which effectively examined differences in size, industry sector and the company's role as an Industry 4.0 provider or user in determining the Industry 4.0-related opportunities and challenges [20]. Following this comprehensive approach investigating the three dimensions of sustainability, we formulated specific hypotheses related to RQ1 and RQ2, aiming at deepening the focus on the perception of environmental sustainability. In this regard, we expect a relatively low perception of Industry 4.0 implementation to be an advantage for the sustainability performance of the companies, regardless of their size and digital level:

Hypothesis 1 (H1). Industry 4.0 is not considered a main advantage related to environmental sustainability.

Hypothesis 2 (H2). Companies do not perceive environmental sustainability as an advantage, regardless of their size in terms of both number of employees and turnover.

Hypothesis 3 (H3). Companies do not perceive environmental sustainability as an advantage, regardless of their digital level.

RQ1 is linked to H1, while RQ2 entails an in-depth discussion following H1 and H2. The next section will provide more details on the methods employed to test the hypotheses, the approach used to collect data and the metrics used to derive the digital level of companies in the considered sample.

\section{Research Methodology}

\subsection{The Online Self-Assessment Tool "Digital Check"}

The assessment of the digital level of companies and the perceived advantages relating to the implementation of Industry 4.0 was part of the survey, distributed among a sample of manufacturing companies associated to Confindustria Marche Nord, the industrial representative association located in Central Italy Marche Region. An online tool named "Digital Check" allowed local companies to self-assess their digital level and readiness for the Industry 4.0 paradigm. The survey was defined considering the general structure and objectives of existing self-assessment tools [51,52] and adapted according to the challenges SMEs face in initiating digital transformation, considering recent scientific works on this topic carried out, among others, by the authors of the present work [31]. The "Digital Check" comprises 26 questions across the following dimensions: (1) Strategy, (2) processes, (3) Industry 4.0, (4) employees, (5) Information Technology (IT) and data security. The current digital level perceived by the individual companies responding to the survey was calculated considering the average of selected questions (see those marked with •) within each dimension as indicated in Table 1. 
Table 1. Structure of the Digital Check.

\begin{tabular}{|c|c|c|}
\hline Dimension & Question & Type \\
\hline \multirow{4}{*}{$\begin{array}{l}\text { D1 } \\
\text { Strategy }\end{array}$} & $\begin{array}{l}\text { Q-1 Degree of definition of a strategy towards } \\
\text { Industry } 4.0 ?\end{array}$ & Likert • \\
\hline & $\begin{array}{l}\text { Q-2 Have you planned intervention related to } \\
\text { Industry } 4.0 \text { over the next two years? }\end{array}$ & Likert \\
\hline & $\begin{array}{l}\text { Q-3 Degree of collaboration with external experts } \\
\text { (e.g., universities, research centres and consulting } \\
\text { agencies) on Industry } 4.0 \text { topics? }\end{array}$ & Likert • \\
\hline & $\begin{array}{l}\text { Q-4 Expected collaborations with external experts } \\
\text { over the next two years? }\end{array}$ & Likert \\
\hline \multirow{5}{*}{$\begin{array}{c}\text { D2 } \\
\text { Processes }\end{array}$} & \multirow{5}{*}{$\begin{array}{l}\text { Q-5 Use of key enabling technologies. } \\
\text { Q-6 Integration of IT in production systems. } \\
\text { Q-7 Flexibility of production systems. } \\
\text { Q-8 Digitalisation of organisation and processes. } \\
\text { Q-9 Impact of Industry } 4.0 \text { on the organisation of the } \\
\text { company. }\end{array}$} & Likert \\
\hline & & Likert• \\
\hline & & Likert • \\
\hline & & Likert • \\
\hline & & Likert \\
\hline \multirow{8}{*}{$\begin{array}{c}\text { D3 } \\
\text { Industry } 4.0\end{array}$} & Q-10 Knowledge about Industry 4.0. & Likert • \\
\hline & $\begin{array}{l}\text { Q-11 Perceived need to increase knowledge about } \\
\text { Industry } 4.0 \text { over the next two years. }\end{array}$ & Likert \\
\hline & Q-12 Relevance of Industry 4.0 for the company. & Likert \\
\hline & $\begin{array}{l}\text { Q-13 Contribution of Industry } 4.0 \text { to the development } \\
\text { of new products/services and business models. }\end{array}$ & Likert • \\
\hline & $\begin{array}{l}\text { Q-14 Expected contribution of Industry } 4.0 \text { to the } \\
\text { development of new products/services and business } \\
\text { models over the next two years. }\end{array}$ & Likert \\
\hline & Q-15 Challenges related to Industry 4.0. & $\begin{array}{l}\text { Multiple } \\
\text { response }\end{array}$ \\
\hline & Q-16 Advantage related to Industry 4.0. & $\begin{array}{l}\text { Multiple } \\
\text { response }\end{array}$ \\
\hline & Q-17 Areas requiring support to local companies. & $\begin{array}{l}\text { Multiple } \\
\text { response }\end{array}$ \\
\hline \multirow{2}{*}{$\begin{array}{c}\text { D4 } \\
\text { Collaborators }\end{array}$} & \multirow{2}{*}{$\begin{array}{l}\text { Q-18 Adequacy of digital skills of collaborators. } \\
\text { Q-19 Perceived need to increase digital competences } \\
\text { of collaborators over the next two years. }\end{array}$} & Likert • \\
\hline & & Likert \\
\hline \multirow{3}{*}{$\begin{array}{l}\text { D5 } \\
\text { Information } \\
\text { Technology }\end{array}$} & Q-20 Degree of use of data from production & Likert \\
\hline & Q-21 Use of cyber-security systems & Likert \\
\hline & Q-22 Degree of data-security & Likert • \\
\hline \multirow{4}{*}{$\begin{array}{c}\text { D6 } \\
\text { Company profile }\end{array}$} & Q-23 Sector. & $\begin{array}{l}\text { Multiple } \\
\text { choice }\end{array}$ \\
\hline & Q-24 Number of employees. & $\begin{array}{l}\text { Multiple } \\
\text { choice }\end{array}$ \\
\hline & Q-25 Yearly turnover (optional question). & $\begin{array}{l}\text { Multiple } \\
\text { choice }\end{array}$ \\
\hline & Q-26 Role of the respondent in the company. & $\begin{array}{l}\text { Multiple } \\
\text { choice }\end{array}$ \\
\hline
\end{tabular}

- Rating considered to calculate average values determining the digital level of companies.

Respondents could rate the questions within each dimension of the survey along a five levels Likert Scale ranging from 1 (low implementation level) to 5 (high implementation level), according to the specific topic of analysis, as shown in the example in Table 2. 
Table 2. Exemplary scale according to topic and dimension in the survey.

\begin{tabular}{ccc}
\hline Dimension & D1 Strategy \\
\hline Question topic & To what extent has your company defined a strategy toward Industry 4.0 \\
\hline & 1 & No strategy has been formulated or planned \\
Scale & 3 & Planning to develop a strategy in the short term \\
& 4 & Development of the strategy currently ongoing \\
& 5 & The strategy is formulated but not yet implemented \\
\hline
\end{tabular}

The overall digital level resulted from the average values assigned by companies to each item object of evaluation across the different dimensions considered. The results of the survey enabled to assign one category portraying the self-assessed digital level of each company taking part to the survey, namely into so called (i) "Digital Newcomers", (ii) "Companies in Transition" and (iii) "Top Performers" (Table 3).

Table 3. Description of digital levels.

\begin{tabular}{cl}
\hline Category & Description \\
\hline Cigital Newcomers & Companies belonging to this level do not consider the transition to \\
(Low digital level) & projects in isolated areas to test possible effects. A concrete strategy for \\
digitization is still under development or not yet at an advanced stage. & Few or none of the production processes support IT integration. The \\
sharing of corporate data and information is still limited. The skills of \\
employees are still inadequate in the Industry 4.0 perspective. \\
Companies belonging to this level demonstrate that they have already \\
incorporated the concept of Industry 4.0 into their strategic orientation. \\
They are taking the first steps towards sharing information both at \\
company level and with business partners. IT services are supported \\
and sometimes incorporated into production processes. In certain areas \\
the skills of employees are proving to be enough to apply/test Industry \\
4.0 concepts. This type of company is not new to collaborations with \\
research institutes and/or strategic consulting firms. \\
Companies of this level are in the advanced stage of implementation \\
of Industry 4.0. A strategy has already been implemented. Investments \\
in multiple areas are either in the planning stage or already underway. \\
The sharing of information at company level between departments and \\
with suppliers is fully or largely integrated. Production processes are \\
integrated with IT systems thanks to which production data are \\
collected and used for monitoring and optimisation of the processes \\
themselves. This type of company has concluded several collaboration \\
experiences with different partners (e.g., applied research institutes, \\
consulting companies, system integrators).
\end{tabular}

The variable representing the digital level of companies will be employed to test the RQ2 of the present study, namely which characteristics of companies may be associated with different perceptions of sustainability, together with other attributes that were subjects of the survey such as size (number of employees) and turnover (EUR) as summarised in Table 4. 
Table 4. Variables.

\begin{tabular}{cccc}
\hline Category & Description & Metrics & Source \\
\hline \multirow{2}{*}{ Size } & 1 Small & $10-49$ employees & \\
& 2 Medium & $50-249$ employees & [53] \\
Turnover & 3 Large & Over 250 employees & \\
& 1 Small & Up to 10 million EUR & 2 Medium \\
Digital level & 3 Large & 11-49 million EUR & Over 50 million EUR \\
& 2 Companies in Transition (medium & Own elaboration & \\
& level) & & \\
\hline
\end{tabular}

A specific question in the survey (Q-16) assesses the advantages of Industry 4.0 perceived by companies, considering the TBL as identified in prior studies and systematically outlined in Table 5.

Table 5. Structure of Q-16: Advantages of Industry 4.0 perceived by companies.

\begin{tabular}{lllc}
\hline \multicolumn{1}{c}{ ID } & \multicolumn{1}{c}{ Advantage } & Triple Bottom Line & Reference \\
\hline Log & Optimization in logistics and warehousing & Economic & {$[54-57]$} \\
TS & Time savings & Economic & {$[58,59]$} \\
Flex & Flexible organisation of work & Social & {$[60,61]$} \\
Qual & Quality (reduction of errors) & Economic & {$[62-64]$} \\
PS & Lower physical stress & Social & {$[65-68]$} \\
Work & Reduction of workforce & Economic & {$[69,70]$} \\
Cost & Reduction of costs & Economic & {$[71,72]$} \\
Sust & Sustainability (lower environmental impact) & Environment & {$[20,73]$} \\
\hline
\end{tabular}

Most advantages included in the survey relate to the economic line that turned out to be relatively more covered by previous related studies in the recent scientific literature. Being a multiple-response question, respondents could express more preferences (in the specific case up to three questions): The typology of the question was considered for the choice of the proper statistical test searching for an association between attributes of the companies such as size, turnover and digital level with the perception of the different advantages related to Industry 4.0 (Section 3.3).

\subsection{Data Collection and Sample}

The data derived with Digital Check were collected via an online survey available to be filled out from 15 October 2018 to 18 November 2018. The survey was managed by Confindustria Marche Nord (regional unit of the General Confederation of Italian Industry) and distributed among a sample of companies operating in the Marche Region (Italy). The sample consists of 65 companies, mainly operating in the machine construction (40\%), chemical (13\%) and footwear $(7 \%)$ sectors. Approximately $70 \%$ of the respondent companies could be classified as SMEs employing less than 250 collaborators and having less than 50 million Euro of yearly turnover (see Table 6).

Table 6. Sample of participating companies according to size.

\begin{tabular}{ccc}
\hline Size & Number & Percent \\
\hline Small & 23 & $35.4 \%$ \\
Medium & 23 & $35.4 \%$ \\
Large & 19 & $29.2 \%$ \\
Total & $\mathbf{6 5}$ & $\mathbf{1 0 0 . 0} \%$ \\
\hline
\end{tabular}


Figure 1 shows the results of the survey and the categorization of the sample into the three digital levels as explained before. A positive result of the survey is that few companies ended up as digital newcomers ( $4.6 \%$ of total) and therefore at the outset of introducing Industry 4.0 and digitalization into their company. While $20.0 \%$ of the respondents belong to the digital top performers, most of the participating companies are in transition and therefore on an average digital level (75.4\%). Taking a further look only to SMEs we can see that especially those that are newcomers are almost all SMEs, while top performers seem to be almost all medium to large companies. It is interesting to note that the companies in the transitional phase consist nearly equally of small, medium-sized and large companies.

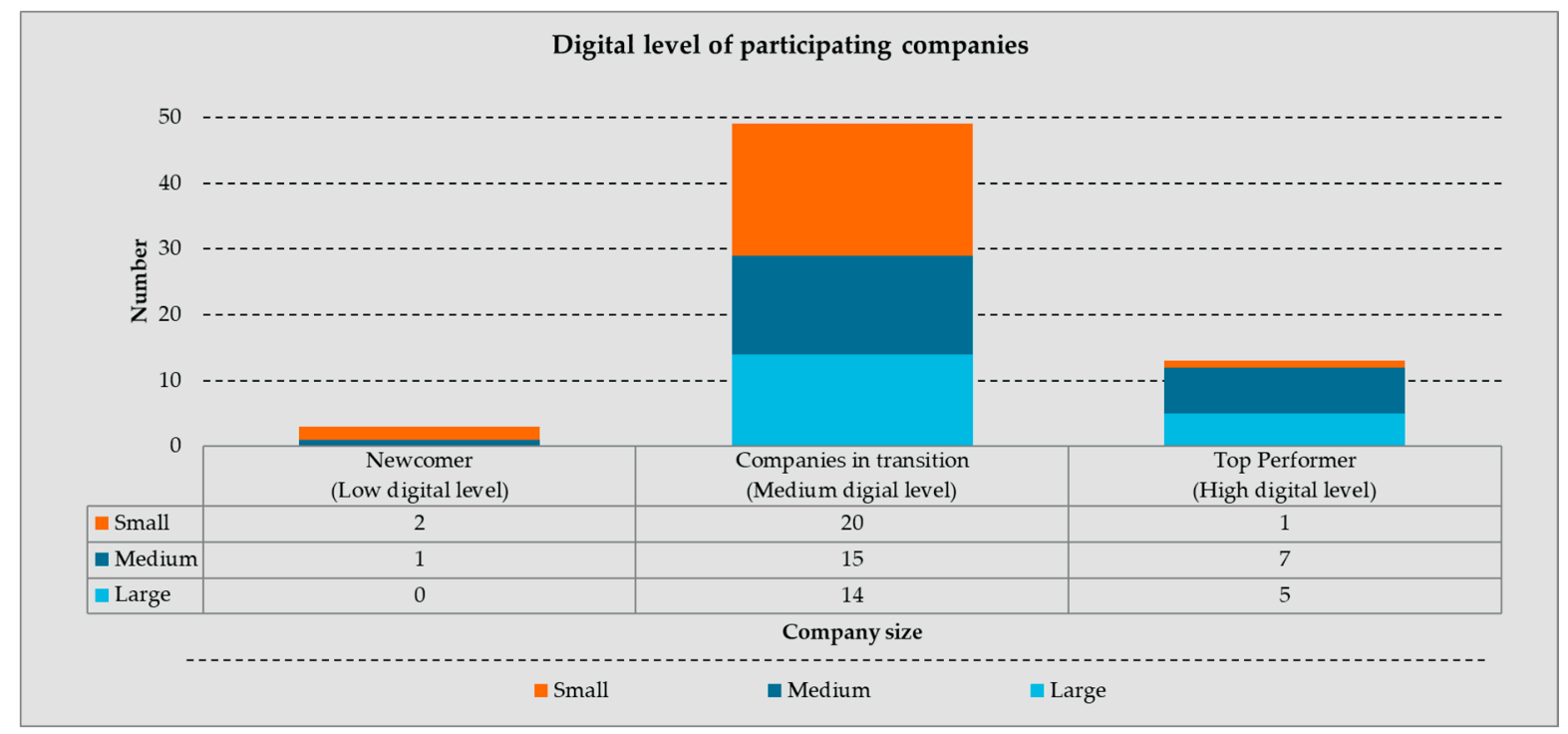

Figure 1. Digital level of participating companies.

\subsection{Data Analysis}

The structure and the results of the Digital Check provide the opportunity to answer the research questions of the present study, and particularly to test whether an association between variables exists. In the analysis, we employed the multiple response to question 16 (Q-16) assigned by companies ordered in different variables, namely size, turnover and digital level, to study whether there are differences in the perceptions of sustainability among a group of companies. The analysis and modelling of categorical variables have been the focus of significant research activities such as [74]. Considering the multiple-response nature of the data, the work of Agresti and Liu and Thomas and Decady were considered $[75,76]$. Pearson Chi-squared test for nominal (categorical) data was performed. For the data analysis, the statistical software SPSS v.19 was employed.

\section{Results}

This section presents the main results of the analysis. Section 4.1 answers RQ1 and the related H1. Sections 4.2-4.4 deal with RQ2. In this regard, while the Sections 4.2 and 4.3 provide evidence to assess H2, Section 4.4 exclusively addresses H3.

\subsection{Advantages Related to Industry 4.0 Implementation}

As shown in Figure 2 the main advantages linked to the adoption of Industry 4.0 concern the possibility of increasing the quality of products through the reduction of errors (63.1\%). Advantages in the management of logistics (53.8\%) and time savings (50.8\%) are also considered major benefit following the implementation of Industry 4.0 concepts. Within the social dimension of sustainability, less than half of the respondents consider Industry 4.0 beneficial to lower physical stress of collaborators $(40.0 \%)$. The percentage decreases with consideration to the advantage related to higher flexibility of 
work (24.6\%). A rather low number of respondents consider Industry 4.0 applications as an opportunity to improve sustainability, e.g., reducing negative environmental impact of manufacturing processes (6.2\%). Regarding RQ1, we conclude overall that companies consider economic sustainability at a higher extent compared to the social and environmental dimension. The consideration of environmental sustainability as an advantage among companies is very low, hence H1 is supported.

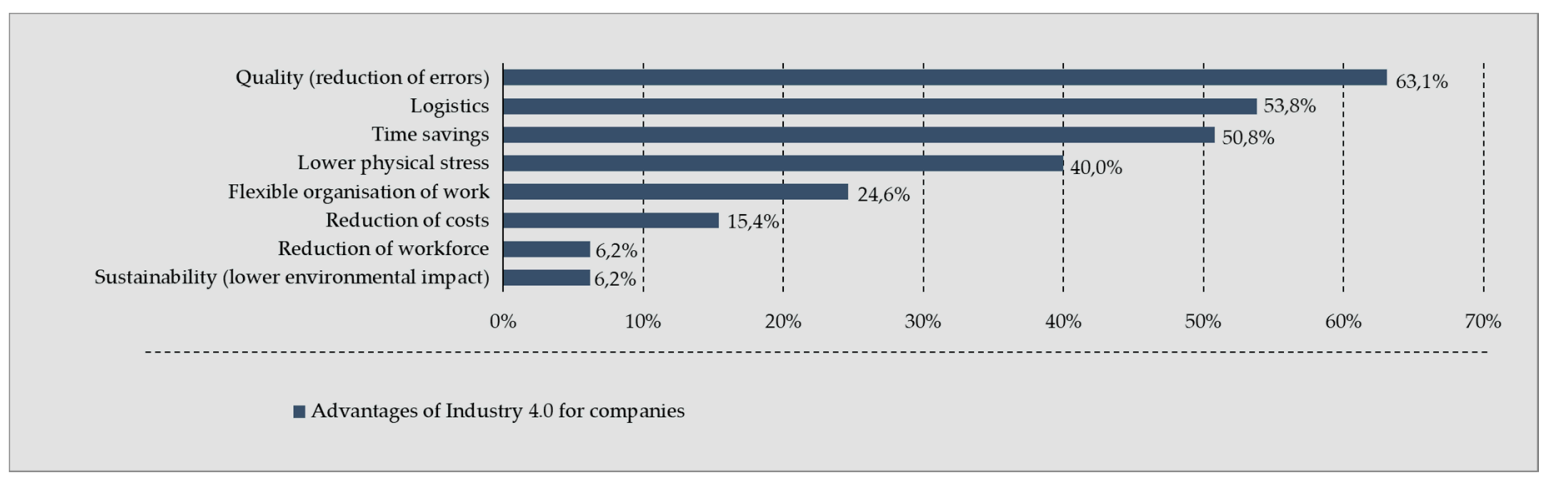

Figure 2. Advantages of Industry 4.0 for companies.

\subsection{Company Size as Variable for Different Associations in the Perception of Sustainability}

The first categorical variable tested for a potential association with the perception of Industry 4.0 as beneficial for sustainability in manufacturing is the size of the company, which considers the number of employees. There is a strong association $\left(\chi^{2}=7.093, p<0.019\right)$ between the size of the company and the beneficial perception of Industry 4.0 in achieving more flexible organisation of work (Table 7). Indeed, only a very marginal percentage of small companies (4.3\%) perceive this aspect of social sustainability as beneficial, against a substantial $34.8 \%$ and $36.8 \%$ of medium and large companies, respectively.

Table 7. Summary table of the joint distributions of size of the companies (rows) and each investigated advantage of Industry 4.0 (columns).

\begin{tabular}{|c|c|c|c|c|c|c|c|c|c|c|c|}
\hline Size & \multicolumn{11}{|c|}{ Advantages } \\
\hline $\mathrm{N}=65$ & Qual & $\log$ & $T S$ & LPS & Flex & & Cost & Work & & Sust & \\
\hline Small & $56.5 \% 13$ & $60.9 \% \quad 14$ & $60.9 \% \quad 14$ & $43.5 \% \quad 10$ & $4.3 \%$ & 1 & $13 \%$ & $4.3 \%$ & 1 & $8.7 \%$ & 2 \\
\hline Medium & $69.6 \% 16$ & $56.5 \% 13$ & $39.1 \% \quad 9$ & $43.5 \% \quad 10$ & $34.8 \%$ & 8 & $21.7 \% \quad 5$ & $4.3 \%$ & 1 & $8.7 \%$ & 2 \\
\hline Large & $63.2 \% \quad 12$ & $42.1 \% \quad 8$ & $52.6 \% \quad 10$ & $31.6 \% \quad 6$ & $36.8 \%$ & 7 & $10.5 \% \quad 2$ & $10.5 \%$ & 2 & $0 \%$ & 0 \\
\hline$x^{2}$ & 0.840 & 1.577 & 2.212 & 0.793 & 7.903 & & 1.155 & 0.889 & & 1.761 & \\
\hline Sig. & 0.657 & 0.455 & 0.331 & 0.673 & 0.019 & & 0.561 & 0.641 & & 0.415 & \\
\hline
\end{tabular}

Considering the variable environmental sustainability as advantage of Industry 4.0, the available data show no significant association $\left(\chi^{2}=1.761, p<0.415\right)$. As for the statistically significant variables referring to RQ2, results suggest a strong association between the size of the company and the advantage of higher flexibility of work organization within the social dimension of sustainability. None of the other advantages related to other dimensions of sustainability (economic and environmental) show a significant association with size. Consequently, $\mathrm{H} 2$ is supported, since environmental sustainability is not perceived as an advantage related to Industry 4.0 regardless of the size of the company.

\subsection{Turnover of the Company as Variable for Different Association in the Perception of Sustainability}

Following the same approach, the categorical variable referring to the yearly turnover of the company (EUR) was tested against the hypothesis of independence with the perception of Industry 4.0 as beneficial for specific economic, social and environmental dimensions concerning sustainability in manufacturing (see Table 8). In this case the number of respondents covers $92.3 \%$ of the entire 
sample $(\mathrm{N}=60)$ since five companies opted for not disclosing their category of yearly turnover. The Chi-Squared statistics indicate the existence of no significant association across the economic, social and environmental advantages proposed, such as cost savings $\left(\chi^{2}=0.051, p<0.0975\right)$, lower physical stress $\left(\chi^{2}=0.008, p<0.996\right)$ and environmental impact $\left(\chi^{2}=4.058, p<0.131\right)$, respectively. The answer to RQ2 is that the variable turnover does not show any significant association to specific advantages related to the economic, social and environmental dimensions of sustainability. Therefore, $\mathrm{H} 2$ is supported.

Table 8. Summary table of the joint distributions of turnover of the companies (rows) and each investigated advantage of Industry 4.0 (columns).

\begin{tabular}{|c|c|c|c|c|c|c|c|c|}
\hline \multirow{2}{*}{$\begin{array}{c}\text { Turnover } \\
\mathrm{N}=60\end{array}$} & \multicolumn{8}{|c|}{ Advantages } \\
\hline & Qual & $\log$ & TS & LPS & Flex & Cost & Work & Sust \\
\hline Small & $63.6 \% \quad 14$ & $54.5 \% \quad 12$ & $59.1 \% 13$ & $40.9 \% \quad 9$ & $9.1 \%$ & $13.6 \% \quad 3$ & $9.1 \% \quad 2$ & $4.5 \%$ \\
\hline Medium & $68.4 \% \quad 13$ & $63.2 \% \quad 12$ & $42.1 \% \quad 8$ & $42.1 \% \quad 8$ & $31.6 \% \quad 6$ & $15.8 \% \quad 3$ & $31.6 \% \quad 6$ & $15.8 \% \quad 3$ \\
\hline Large & $63.2 \% \quad 12$ & $47.4 \% \quad 9$ & $42.1 \% \quad 8$ & $42.1 \% \quad 8$ & $36.8 \% \quad 7$ & $15.8 \% \quad 3$ & $36.8 \% \quad 7$ & $0 \%$ \\
\hline$x^{2}$ & 0.144 & 0.960 & 1.610 & 0.008 & 4.829 & 0.051 & 0.328 & 4.058 \\
\hline Sig & 0.930 & 0.619 & 0.447 & 0.996 & 0.089 & 0.975 & 0.849 & 0.131 \\
\hline
\end{tabular}

\subsection{Digital Level as Variable for Different Association in the Perception of Sustainability}

Finally, a test was performed to investigate whether the digital level of the company is associated with advantages related to Industry 4.0 applications (see Table 9). The Chi-Squared statistics indicate the existence of a significant association between the advantage of Industry 4.0 for logistics and the digital level of the company $\left(\chi^{2}=8.035, p<0.018\right)$. This provides an additional element to answer RQ2 since the variable digital level results associated to a specific advantage of Industry 4.0 related to the economic dimension of sustainability and related to the optimisation of logistics and warehousing. The association of Industry 4.0 as beneficial for environmental sustainability remains low $\left(\chi^{2}=0.250\right)$, regardless of the digital level of companies. Consequently, $\mathrm{H} 2$ is supported.

Table 9. Summary table of the joint distributions of the digital level of the companies (rows) and each investigated advantage of Industry 4.0 (columns).

\begin{tabular}{|c|c|c|c|c|c|c|c|c|c|}
\hline \multicolumn{5}{|c|}{ Digital Level } & \multicolumn{5}{|c|}{ Advantages } \\
\hline$N=65$ & Qual & $\log$ & TS & LPS & Flex & Cost & Work & Sust & \\
\hline Low & $66.7 \% \quad 2$ & $0 \%$ & $33.3 \% \quad 1$ & $66.7 \% \quad 2$ & $0 \%$ & $0 \%$ & $0 \%$ & $0 \%$ & 0 \\
\hline Medium & $61.2 \% \quad 30$ & $63.3 \% \quad 31$ & $53.1 \% \quad 26$ & $40.8 \% \quad 20$ & $22.4 \% \quad 11$ & $14.3 \% \quad 7$ & $22.4 \% \quad 11$ & $6.1 \%$ & 3 \\
\hline High & $69.2 \% \quad 9$ & $30.8 \% \quad 35$ & $46.2 \% \quad 6$ & $30.8 \% \quad 4$ & $38.5 \% \quad 5$ & $23.1 \% \quad 3$ & $38.5 \% \quad 5$ & $7.7 \%$ & 1 \\
\hline$x^{2}$ & 0.300 & 8.035 & 0.579 & 1.364 & 2.447 & 1.182 & 2.447 & 0.250 & \\
\hline$\widehat{\mathrm{Sig}}$ & 0.861 & 0.018 & 0.749 & 0.506 & 0.249 & 0.554 & 0.294 & 0.882 & \\
\hline
\end{tabular}

\section{Discussion}

\subsection{General Discussion of Results}

The present research studied whether differences exist in the perception of the advantages related to the implementation of Industry 4.0 within a sample of manufacturing companies located in the Marche Region (Italy). In particular, the existence of differences in the association of Industry 4.0 to specific economic, social and environmental sustainability concerns was investigated considering as the explanatory variable "company specific characteristics" such as number of employees, yearly turnover and digital level. With respect to the RQ1 formulated in the present paper, the overall analysis of the sample indicates that companies in general rate economic advantages among the most relevant factors, compared to other social and environmental benefits, resulting from Industry 4.0. This evidence is aligned to the existing literature, indicating a consistent number of economic opportunities at the base of the implementation of Industry 4.0 technologies and concepts, which can also be gained in the 
context of SMEs [77,78]. Similar conclusions were drawn from other studies in relation to the most recurrent advantages rated in the sample object of the present research, such as quality (reduction of errors) and logistics $[79,80]$. Furthermore, the relatively low perception in terms of reduction of workforce, following Industry 4.0, complies with the current literature on the topic, portraying unified perspectives on potential gain or loss in the number of employees in industry [81]. Social aspects of sustainability, such as more flexible organisation of work and lower physical stress, contributing to improved working environment for employees, have been rated overall of secondary importance, although previous studies acknowledged such aspects as drivers for Industry 4.0 implementation [20]. Environmental opportunities emerge as irrelevant drivers relating to the implementation of Industry 4.0, within the considered sample. A very limited number of respondents declared considering Industry 4.0 as an opportunity to improve their companies. This evidence differs from the findings of previous studies [82], indicating environmental opportunities as relevant drivers for a tendency towards Industry $4.0[20,28]$. Another relevant study on this field showed with a higher degree of details that green production in general, as well as energy and resource management, resulted as high priority within the surveyed sample of companies [22]. The results of this analysis offered enough elements to confirm the proposed $\mathrm{H} 1$, acknowledging the absence of sustainable opportunities influencing the tendency for Industry 4.0 implementation. Consequently, at the aggregate level of the sample, economic opportunities are considered prominent.

Answering RQ2 implied studying the opportunities associated to Industry 4.0 according to different characteristics of the sample such as size, turnover and digital level. With respect to company size in terms of employees, the findings for RQ2 revealed the existence of a stronger association for large companies regarding the perceived social opportunity, related to the higher flexibility in the organisation of work. The latter is acknowledged as being enabled by Industry 4.0 [58] and in terms of reshaping organisations is considered a driver for sustainability [83]. In the literature, SMEs are recognised for their higher degree of flexibility compared to large companies [84], due to specific characteristics already enabling them to react to increasingly volatile market conditions [85]. This aspect may explain the higher relevance attributed by larger companies to Industry 4.0 implementation as potentially nurturing their demand for higher flexibility. Considering the advantage of cost, our research did not find any association with size. In this respect a recent study identified a greater relevance of this advantage for larger companies, such as multinational enterprises, compared to SMEs due to their higher cost reduction and profitability expectations [86]. There is no strong association of Industry 4.0 to environmental sustainability, regardless of the size of the companies. For this reason, the proposed $\mathrm{H} 2$ is confirmed.

The analysis considering yearly level of turnover did not show significant associations to specific Industry 4.0 related advantages. This confirmed our initial hypothesis (H2), related to the turnover as a potential variable resulting in different associations to environmental sustainability among companies. Several scholars argue that the lack of financial resources in general may represent a main constraint to the implementation of Industry 4.0 concepts, particularly across SMEs [87-89]. In this respect, the results of our study could not indicate clear directions on whether large companies, due to their higher investment capabilities, rate specific advantages differently compared to SMEs.

The results obtained analysing the digital level against the different advantages relating to Industry 4.0 do not show any significance association for environmental and social sustainability. Therefore, companies of the sample, regardless of their digital level, as proposed in H3, do not associate significantly environmental sustainability as a driving advantage for application of Industry 4.0. In this regard, the results indicate for $\mathrm{RQ} 2$ a rather stronger association for economic sustainability, such as the opportunity for optimization of logistics and warehousing, among companies rated with a higher digital level, namely companies in transition and top-performer. Reviewing the scientific literature on the topic, we noted that the association between digital level and the perceived advantages relating to Industry 4.0 implementation appears have limited assessment. While the existence of assessment of the adoption of specific typologies of technologies according to the maturity level of implementation 
of Industry 4.0 is acknowledged [90], the review of existing literature did not yield to the identification of studies analysing the aforementioned association between digital level and advantages of Industry 4.0. While not relating to social or environmental sustainability, we observe that companies with a higher digital level consider the advantages of Industry 4.0 for efficient logistics and warehousing more relevant, compared to less digitalised companies. Considering the limited number of similar studies on this specific matter, it is challenging to draw further conclusions in comparison with existing literature. A partial explanation for this association can be suggested considering the general large size of companies which achieved the highest digital level (top performer) within the considered sample. In this respect, large companies may consider Industry 4.0 applications more relevant for logistics, being more advanced in integrating information technology systems into their production facilities compared to SMEs facing more obstacles to their integration in digital supply chain [91,92].

\subsection{Implications for Practitioners and Academia}

The results of this study are relevant for researchers as well as for practitioners from industry and especially managers of SMEs. As already seen in the literature review there is a lack of investigation concerning the current status as well as opportunities for the introduction of Industry 4.0 and digitalization in companies. To be precise, the literature review showed that there are lots of contributions to presenting different concepts and technologies for Industry 4.0, but not that many works that give an insight into already ongoing projects to introduce Industry 4.0 or its results. With this work and survey, we provide information from the perspective of companies themselves and how they see the impact and advantages of Industry 4.0 regarding economic, social and environmental aspects.

The study provides valuable information for practitioners and mangers of SMEs. First of all, the study used a self-assessment tool adapted to the needs of SMEs to assess the current status of companies in introducing Industry 4.0. The results show that almost all companies started to deal with the introduction of Industry 4.0. This is an important result for all those companies that did not yet start to implement any kind of measure, as it would mean that they are already far behind most companies and thus that intervention measures are compelling. In addition, this kind of benchmarking data shows also that for most of the companies there is still a long way to go to be fully digitalized and to become a top-performer.

An unfortunately sobering result of this study is that most of the companies (including SMEs as well as large enterprises) do not perceive Industry 4.0 as a chance to enhance sustainability (especially environmental and social sustainability). This should be an important input for researchers working in the area of Industry 4.0 and sustainability, as it shows that there is still a need to raise awareness of the opportunities arising from the introduction of Industry 4.0 to increase sustainability and performance aspects as already shown by recent studies $[73,93,94]$. In this respect, these results may suggest that, e.g., regional business and industrial associations update accordingly the programs offered on digital transformation and Industry 4.0 toward the topics increasingly relevant but currently less mastered by companies, such as the social and environmental opportunities of Industry 4.0. In addition, there seems to be a general lack of enterprises in perceiving sustainability as an important aim for the future, combining long-term economic aspects with social and environmental aspects. Therefore, it will be important for the future to conduct, e.g., case study research in order to provide information of real case studies where Industry 4.0 contributes to increasing sustainability and at the same time to improving the overall performance of the company. Targeted actions could also consist in knowledge transfer, providing more information about the relationship between Industry 4.0 and sustainability. As the lack of perception of advantages of Industry 4.0 concerning sustainability seems to be evident not only for SMEs, but also for large companies, further studies should also motivate large companies with higher financial and human resources to take a first step in implementing measures. Table 10 summarizes all identified implications in a sort of action plan. 
Table 10. Sample of participating companies according to size.

\begin{tabular}{|c|c|c|c|}
\hline $\mathbf{N}^{\circ}$ & Result of this study & Derived Actions & Interested Parties \\
\hline 1 & $\begin{array}{l}\text { SMEs participating in this } \\
\text { study learned a lot from } \\
\text { conducting the } \\
\text { self-assessment. }\end{array}$ & $\begin{array}{l}\text { SMEs should take advantage of } \\
\text { offered self-assessment tools to } \\
\text { identify the current status in } \\
\text { introducing Industry 4.0. }\end{array}$ & Practitioners in SMEs \\
\hline 2 & $\begin{array}{c}\text { Almost all companies started } \\
\text { to deal with the introduction } \\
\text { of Industry } 4.0 .\end{array}$ & $\begin{array}{l}\text { Intervention measures are } \\
\text { compelling for all those SMEs that } \\
\text { have not yet started to introduce } \\
\text { Industry } 4.0 .\end{array}$ & Practitioners in SMEs \\
\hline 3 & $\begin{array}{c}\text { Most of the companies are not } \\
\text { yet top performer. }\end{array}$ & $\begin{array}{l}\text { SMEs need to define a long-term } \\
\text { oriented strategy with the aim to } \\
\text { become top performer. }\end{array}$ & Practitioners in SMEs \\
\hline 4 & $\begin{array}{l}\text { Most of the companies do not } \\
\text { perceive Industry } 4.0 \text { as a } \\
\text { chance to enhance } \\
\text { sustainability. }\end{array}$ & $\begin{array}{l}\text { Revise programs and offer of } \\
\text { initiatives to increase the } \\
\text { awareness of social and } \\
\text { environmental opportunities of } \\
\text { Industry } 4.0 .\end{array}$ & $\begin{array}{c}\text { Regional and Industrial } \\
\text { Associations }\end{array}$ \\
\hline 5 & $\begin{array}{l}\text { Most of the companies do not } \\
\text { perceive Industry } 4.0 \text { as a } \\
\text { chance to enhance } \\
\text { sustainability. }\end{array}$ & $\begin{array}{l}\text { Conduct research to raise } \\
\text { awareness of the opportunities of } \\
\text { Industry } 4.0 \text { to increase } \\
\text { performance as well as } \\
\text { sustainability aspects. }\end{array}$ & Researchers in Academia \\
\hline 6 & $\begin{array}{c}\text { Lack of information from real } \\
\text { case studies where Industry } \\
4.0 \text { contributed to increase } \\
\text { sustainability. }\end{array}$ & $\begin{array}{l}\text { Conduct case study research to } \\
\text { provide best practice examples }\end{array}$ & $\begin{array}{l}\text { Researchers in Academia } \\
\text { together with } \\
\text { practitioners from } \\
\text { industry }\end{array}$ \\
\hline 7 & $\begin{array}{l}\text { Missing knowledge transfer } \\
\text { regarding the relationship } \\
\text { between Industry } 4.0 \text { and } \\
\text { sustainability }\end{array}$ & $\begin{array}{l}\text { Conduct research on the } \\
\text { relationship of Industry } 4.0 \text { and } \\
\text { sustainability }\end{array}$ & Researchers in Academia \\
\hline
\end{tabular}

\subsection{Limitations}

We want to note that our study might have certain limitations that need to be considered. While we consider the size of the sample with 65 companies as sufficient to derive generalized results and hypotheses, we are conscious of the fact that all companies are located in one specific geographical region in Italy. The study is therefore representative for all rural regions in Italy or Europe with the similar characteristics of industry sectors and company size, while there might be differences in the perception between the participating companies in this study and, e.g., companies in urban regions and heavily industrialized areas or large cities.

Further, the study was mainly targeted to assess the current state in the introduction of Industry 4.0 in the region of Marche in Italy with only a partial focus on sustainability aspects. Therefore, future research should be conducted to focus and further investigate the relationship between Industry 4.0 and sustainability. This will enable defining more specific relations between sustainability and Industry 4.0 in specific domains and to explore innovative ways to enhance the improvement of either economic or social and environmental performance and contribution of companies. Future research directions, deepening the discourse about sustainability in SMEs approached in the present study, should extend the focus of the analysis to the realm of circular economy and Industry 4.0. This foresees the development of targeted tools assessing the degree of circular economy, adapted to the requirements of SMEs, similar to the methodological work and considerations undertaken to define the structure and metrics of the self-assessment tool for digital readiness employed in the present study.

We exclude any subjective influence on the part of the research team, as data has been taken directly and without any subjective assessment or modification and evaluated using statistical methods and software. 


\section{Conclusions and Outlook}

This work deals with the investigation of the advantages in the application of Industry 4.0 for sustainability. It presents the partial results of a larger survey-based study with 65 companies from the Marche region in Italy. Two research questions were set up for the study and answered based on the results. The first research question deals with whether Industry 4.0 is seen as beneficial for sustainability, considering the economic, environmental and social dimension. The results confirm the initial hypothesis (H1) that currently Industry 4.0 is not seen as beneficial for achieving environmental sustainability by most of the companies. The advantages relating to the economic dimensions of sustainability prevail also over social considerations of sustainability. The second research question deals with whether there are different views on this aspect depending on factors such as size, turnover or the digital level of the companies. Two hypotheses were also put forward that were also confirmed by the data. The first of these two hypothesis (H2) is that companies, regardless of their size (small, medium, large) and level of turnover (small, medium, large), do not consider Industry 4.0 to be advantageous for achieving environmental sustainability. The other hypothesis (H3) is that Industry 4.0 is not considered beneficial for environmental sustainability, regardless of the current digital level of companies.

While it has been shown that some recent research indicates positive links between Industry 4.0 and environmental sustainability, the results of this study show that companies are not fully aware of them. Overall, it is evident that issues such as social and environmental sustainability are often neglected by companies to the benefit of economic sustainability. We therefore see a great need for actions for knowledge transfer in the future, but also to prove a positive correlation between Industry 4.0, sustainability and the performance of companies through applied research and real industrial case studies.

Author Contributions: R.B. developed the overall research design; D.F. worked on the systematic literature review and data analysis; E.R. contributed validating the findings considering the ongoing scientific debate and related implications for practitioners and academia; D.T.M. supervised the correct framing of the proposed concept within the scientific context of the topics discussed. All authors have read and agreed to the published version of the manuscript.

Funding: The APC was funded by the project "SME 4.0-Industry 4.0 for SMEs" (European Union's Horizon 2020 R\&I programme under the Marie Skłodowska-Curie grant agreement No 734713).

Acknowledgments: This work belongs to the project "SME 4.0-Industry 4.0 for SMEs" (funded in the European Union's Horizon 2020 R\&I programme under the Marie Skłodowska-Curie grant agreement No 734713) and the project "SCENA" (CIG: 7417905858D9 funded by Fondirigenti). The authors would like to thank Confindustria Marche, Federmanager and all the participating local institutions for the fruitful collaboration.

Conflicts of Interest: The authors declare no conflict of interest.

\section{References}

1. Platform Industry 4.0. Available online: https://www.plattform-i40.de/PI40/Navigation/EN/Home/home.html (accessed on 7 December 2019).

2. Pfohl, H.-C.; Yahsi, B.; Kurnaz, T. The Impact of Industry 4.0 on the Supply Chain. Innovations and Strategies for Logistics and Supply Chains. Proocedings of the International Conference of Logistics (HICL), Hamburg, Germany, 24-25 September 2015.

3. Andulkar, M.; Le, D.T.; Berger, U. A multi-case study on Industry 4.0 for SME's in Brandeburg, Germany. In Proceedings of the 51st International Conference on System Sciences, Honolulu, Hawaii, 3-6 January 2018; pp. 4544-4553.

4. Schröder, C. The Challenges of INDUSTRY 4.0 for Small and Medium-sized Enterprises; Friedrich-Ebert-Stiftung: Bonn, Germany, 2017.

5. Rauch, E.; Dallasega, P.; Matt, D.T. Critical Factors for Introducing Lean Product Development to Small and Medium Sized Enterprises in Italy. Procedia CIRP 2017, 60, 362-367. [CrossRef]

6. Bauer, W.; Schulund, W.; Marrenbach, D.; Ganshar, O. Industrie 4.0-Volkswirttschafliches Potenzial fur Deutschland; BITKOM: Berlin, Germany, 2014. 
7. Lasinio, C.J.; Lucchetti, F.; Perani, G.; Rinaldi, M.; Zeli, A.; Zurlo, D. Il Piano Nazionale Impresa 4.0: Prime Valutazioni; ISTAT: Rom, Italy, 2018.

8. Spath, D.; Ganschar, O.; Gerlach, S.; Hämmerle, M.; Krause, T.; Schlund, S. Manufacturing Work of the Future-Industry 4.0; Fraunhofer Verlag: Stuttgart, Germany, 2013.

9. Wenking, M.; Benninghaus, C.; Friedli, T. Umsetzungsbarrieren und -lösungen von Industrie 4.0: Welche Faktoren limitieren die Produktion der Zukunft? ZWF 2016, 111, 847-850. [CrossRef]

10. Baum, G. Innovation as the basis for the next industrial revolution. In Industry 4.0-Control of Industrial Complexity with SysLM (in German); Springer: Berlin/Heidelberg, Germany, 2013.

11. Ghobakhloo, M. Industry 4.0, Digitization, and Opportunities for Sustainability. J. Clean. Prod. 2020, 252, 119869. [CrossRef]

12. Stock, T.; Seliger, G. Opportunities of Sustainable Manufacturing in Industry 4.0. Procedia CIRP 2016, 40, 536-541. [CrossRef]

13. Prause, G. Sustainable business models and structures for Industry 4.0. J. Secur. Sustain. Issues 2015, 5, 159-169. [CrossRef]

14. Kiel, D.; Müller, J.M.; Arnold, C.; Voigt, K.-I. Sustainable industrial value creation: Benefits and challenges of industry 4.0. Int. J. Innov. Mgt. 2017, 21, 1740015. [CrossRef]

15. Jensen, J.P.; Remmen, A. Enabling Circular Economy through Product Stewardship. Procedia Manuf. 2017, 8, 377-384. [CrossRef]

16. Tortorella, L.G.; Fettermann, D. Implementation of Industry 4.0 and lean production in Brazilian manufacturing companies. Int. J. Prod. Res. 2018, 56, 2975-2987. [CrossRef]

17. Ender, J.; Wagner, J.C.; Kunert, G.; Guo, F.B.; Larek, R.; Pawletta, T. Concept of a self-learning workplace cell for worker assistance while collaboration with a robot within the self-adapting-production-planning-system. IAPGOS 2019, 9, 4-9. [CrossRef]

18. Hirsch-Kreinsen, H. Smart production systems: A new type of industrial process innovation. In Proceedings of the 2014 DRUID Society Conference, Copenhagen, Denmark, 16-18 June 2014.

19. Littig, B.; Griessler, E. Social Sustainability: A Catchword between Political Pragmatism and Social Theory. Int. J. Sust. Dev. 2005, 8, 65-78. [CrossRef]

20. Müller, J.M.; Kiel, D.; Voigt, K.-I. What Drives the Implementation of Industry 4.0? The Role of Opportunities and Challenges in the Context of Sustainability. Sustainability 2018, 10, 247. [CrossRef]

21. Beier, G.; Niehoff, S.; Ziems, T.; Xue, B. Sustainability Aspects of a Digitalized Industry-A Comparative Study from China and Germany. Int. J. Pr. Eng. Man.-GT. 2017, 4, 227-234. [CrossRef]

22. Gabriel, M.; Pessel, E. Industry 4.0 and sustainability impacts: Critical discussion of sustainability aspects with a special focus on future of work and ecological consequences. Int. J. Eng. 2016, 1, 131-136.

23. Elkington, J. Towards the Sustainable Corporation: Win-Win-Win Business Strategies for Sustainable Development. Calif. Manage. Rev. 1994, 36, 90-100. [CrossRef]

24. Giret, A.; Trentesaux, D.; Prabhu, V. Sustainability in manufacturing operations scheduling: A state of the art review. J. Manuf. Syst. 2015, 37, 126-140. [CrossRef]

25. Mcwilliams, A.; Parhankangas, A.; Coupet, J.; Welch, E.; Barnum, D. Strategic Decision Making for the Triple Bottom Line. Bus. Strateg. Environ. 2014. [CrossRef]

26. Markley, M.; Davis, L. Exploring Future Competitive Advantage through Sustainable Supply Chains. Int. J. Phys. Distr. Log. 2007, 37, 763-774. [CrossRef]

27. Zampou, E.; Plitsos, S.; Karagiannaki, A.; Mourtos, I. Towards a framework for energy-aware information systems in manufacturing. Comput. Ind. 2014, 65, 419-433. [CrossRef]

28. Kagermann, H.; Wahlster, W.; Helbig, J. Reccomendations for Implementing the Strategic Initiative Industrie 4.0; acatec -National Academy of Science and Engineering: München, Deutschland, 2013.

29. Schwab, K. The Fourth Industrial Revolution; Crown Business: New York, NY, USA, 2016.

30. Liao, Y.; Deschamps, F.; Rocha Loures, E.; Ramos, L. Past, present and future of Industry 4.0-a systematic literature review and research agenda proposal. Int. J. Prod. Res. 2017, 55. [CrossRef]

31. Brozzi, R.; D’Amico, R.D.; Pasetti Monizza, G.; Marcher, C.; Riedl, M.; Matt, D. Design of Self-Assessment Tools to Measure Industry 4.0 Readiness. A Methodological Approach for Craftsmanship SMEs. In Product Lifecycle Management to Support Industry 4.0; Chiabert, P., Bouras, A., Noël, F., Ríos, J., Eds.; Springer: Berlin/Heidelberg, Germany, 2018; pp. 566-578. 
32. Matt, D.; Rauch, E. Chancen Zur Bewältigung Des Fachkräftemangels in KMU Durch Die Urbane Produktion von Morgen (Opportunities to address shortages in qualified staff in SMEs through the Urban Production of tomorrow). In Industrie 4.0 Wie Intelligente Vernetzung und Kognitive Systeme Unsere Arbeit Verändern; Lödding, H., Kersten, W., Koller, H., Eds.; Gito Verlag: Berlin, Germany, 2014; pp. 155-176.

33. de Sousa Jabbour, A.B.L.; Jabbour, C.J.C.; Foropon, C.; Godinho Filho, M. When titans meet-Can industry 4.0 revolutionise the environmentally-sustainable manufacturing wave? The role of critical success factors. Technol. Forecast. Soc. 2018, 132, 18-25. [CrossRef]

34. Morelli, J. Environmental Sustainability: A Definition for Environmental Professionals. J. Environ. Sustain. 2011, 1, 1-10. [CrossRef]

35. Vance, L.; Eason, T.; Cabezas, H. Energy sustainability: Consumption, efficiency, and environmental impact. Cleam. Techn. Environ. Policy 2015, 17, 1781-1792. [CrossRef]

36. Bonilla, S.; Silva, H.; Terra da Silva, M.; Franco Gonçalves, R.; Sacomano, J. Industry 4.0 and Sustainability Implications: A Scenario-Based Analysis of the Impacts and Challenges. Sustainability 2018, 10, 3740. [CrossRef]

37. Müller, J.; Dotzauer, V.; Voigt, K. Industry 4.0 and its Impact on Reshoring Decisions of German Manufacturing Enterprises. In Supply Management Research. Advanced Studies in Supply Management; Bode, C., Bogaschewsky, R., Eßig, M., Lasch, R., Stölzle, W., Eds.; Springer: Berlin/Heidelberg, Germany, 2017; pp. 165-179.

38. Gebler, M.; Schoot Uiterkamp, A.J.M.; Visser, C. A global sustainability perspective on 3D printing technologies. Energy Policy 2014, 74, 158-167. [CrossRef]

39. Qiu, X.; Luo, H.; Xu, G.; Zhong, R.; Huang, G.Q. Physical assets and service sharing for IoT-enabled Supply Hub in Industrial Park (SHIP). Int. J. Prod. Econ. 2015, 159, 4-15. [CrossRef]

40. Hermann, M.; Pentek, T.; Otto, B. Design Principles for Industrie 4.0 Scenarios. In Proceedings of the 49th Hawaii International Conference on Systems Sciences (HICSS), Honolulu, HI, USA, 5-8 January 2016.

41. Ding, K.; Jiang, P.; Zheng, M. Environmental and economic sustainability-aware resource service scheduling for industrial product service systems. J. Intell. Manuf. 2017, 28, 1303-1316. [CrossRef]

42. Fysikopoulos, A.; Pastras, G.; Alexopoulos, T.; Chryssolouris, G. On a generalized approach to manufacturing energy efficiency. Int. J. Adv. Manuf. Technol. 2014, 73, 1437-1452. [CrossRef]

43. Pfeffer, J. Building Sustainable Organizations: The Human Factor. Acad. Manag. Perspect. 2010, 24. [CrossRef]

44. Gualtieri, L.; Rojas, R.; Carabin, G.; Palomba, I.; Rauch, E.; Vidoni, R.; Matt, D.T. Advanced Automation for SMEs in the I4.0 Revolution: Engineering Education and Employees Training in the Smart Mini Factory Laboratory. In Proceedings of the 2018 IEEE International Conference on Industrial Engineering and Engineering Management (IEEM), Bangkok, Thailand, 16-19 December 2018; pp. 1111-1115.

45. Rojas, R.; Rauch, E.; Dallasega, P.; Matt, D.T. Safe Human-Machine Centered Design of an Assembly Station in a Learning Factory Environment. In Proceedings of the International Conference on Industrial Engineering and Operations Management, Bandung, Indonesia, 6-8 March 2018; pp. 403-411.

46. Gualtieri, L.; Rauch, E.; Rojas, R.; Vidoni, R.; Matt, D. Application of Axiomatic Design for the Design of a Safe Collaborative Human-Robot Assembly Workplace. MATEC Web Conf. 2018, 223, 01003. [CrossRef]

47. Mark, B.G.; Hofmayer, S.; Rauch, E.; Matt, D.T. Inclusion of Workers with Disabilities in Production 4.0: Legal Foundations in Europe and Potentials Through Worker Assistance Systems. Sustainability 2019, 11, 5978. [CrossRef]

48. Schulte, J.; Hallstedt, S.I. Self-Assessment Method for Sustainability Implementation in Product Innovation. Sustainability 2018, 10, 4336. [CrossRef]

49. Elkington, J. Partnerships from Cannibals with Forks: The Triple Bottom Line of 21st-Century Business. Environ. Qual. Manag. 1998, 8, 37-51. [CrossRef]

50. Norman, W.; MacDonald, C. Getting to the Bottom of "Triple Bottom Line". Bus. Ethics Q. 2004, 14, $243-262$. [CrossRef]

51. Schumacher, A.; Erol, S.; Sihn, W. A Maturity Model for Assessing Industry 4.0 Readiness and Maturity of Manufacturing Enterprises. Procedia CIRP 2016, 52, 161-166. [CrossRef]

52. Matt, D.T.; Rauch, E.; Riedl, M. Knowledge Transfer and Introduction of Industry 4.0 in SMEs: A Five-Step Methodology to Introduce Industry 4.0. In Analyzing the Impacts of Industry 4.0 in Modern Business Environments; Jirsák, P., Bureš, V., Eds.; IGI Global: Pennsylvania, PA, USA, 2018; pp. 256-282. 
53. European Commission. Available online: https:/ec.europa.eu/growth/smes/business-friendly-environment/ sme-definition_en (accessed on 12 March 2020).

54. Barreto, L.; Amaral, A.; Pereira, T. Industry 4.0 Implications in Logistics: An Overview. Procedia Manuf. 2017, 13, 1245-1252. [CrossRef]

55. Schmidt, R.; Möhring, M.; Härting, R.-C.; Reichstein, C.; Neumaier, P.; Jozinović, P. Industry 4.0-Potentials for Creating Smart Products: Empirical Research Results. In Business Information Systems; Abramowicz, W., Ed.; Springer: Berlin/Heidelberg, Germany, 2015; pp. 16-27.

56. Schuhmacher, J.; Hummel, V. Decentralized Control of Logistic Processes in Cyber-Physical Production Systems at the Example of ESB Logistics Learning Factory. Procedia CIRP 2016, 54, 19-24. [CrossRef]

57. Zhong, R.Y.; Huang, G.Q.; Lan, S.; Dai, Q.Y.; Chen, X.; Zhang, T. A Big Data Approach for Logistics Trajectory Discovery from RFID-Enabled Production Data. Int. J. Prod. Econ. 2015, 165, 260-272. [CrossRef]

58. Tirabeni, L.; De Bernardi, P.; Forliano, C.; Franco, M. How Can Organisations and Business Models Lead to a More Sustainable Society? A Framework from a Systematic Review of the Industry 4.0. Sustainability 2019, 11, 6363. [CrossRef]

59. Davies, R.; Coole, T.; Smith, A. Review of Socio-Technical Considerations to Ensure Successful Implementation of Industry 4.0. Procedia Manuf. 2017, 11, 1288-1295. [CrossRef]

60. Peukert, B.; Benecke, S.; Clavell, J.; Neugebauer, S.; Nissen, N.F.; Uhlmann, E.; Lang, K.-D.; Finkbeiner, M. Addressing Sustainability and Flexibility in Manufacturing Via Smart Modular Machine Tool Frames to Support Sustainable Value Creation. Procedia CIRP 2015, 29, 514-519. [CrossRef]

61. Brettel, M.; Klein, M.; Friederichsen, N. The Relevance of Manufacturing Flexibility in the Context of Industrie 4.0. Procedia CIRP 2016, 41, 105-110. [CrossRef]

62. Rüßmann, M.; Lorenz, M.; Gerbert, P.; Waldner, M.; Justus, J.; Engel, P.; Harnisch, M. Industry 4.0: The Future of Productivity and Growth in Manufacturing; BCG: Boston, MA, USA, 2015.

63. Oliff, H.; Liu, Y. Towards Industry 4.0 Utilizing Data-Mining Techniques: A Case Study on Quality Improvement. Procedia CIRP 2017, 63, 167-172. [CrossRef]

64. Shibin, K.T.; Gunasekaran, A.; Papadopoulos, T.; Childe, S.J.; Dubey, R.; Singh, T. Energy Sustainability in Operations: An Optimization Study. Int. J. Adv. Manuf. Technol. 2016, 86, 2873-2884. [CrossRef]

65. Rönick, K.; Kremer, T.; Wakula, J. Evaluation of an Adaptive Assistance System to Optimize Physical Stress in the Assembly. In Proceedings of the 20th Congress of the International Ergonomics Association (IEA 2018), Florence, Italy, 26-30 June 2018; Bagnara, S., Tartaglia, R., Albolino, S., Alexander, T., Fujita, Y., Eds.; Springer: Berlin/Heidelberg, Germany, 2019; pp. 576-584.

66. Romero, D.; Bernus, P.; Noran, O.; Stahre, J.; Fast-Berglund, Å. The Operator 4.0: Human Cyber-Physical Systems \& Adaptive Automation towards Human-Automation Symbiosis Work Systems. In Advances in Production Management Systems, Initiatives for a Sustainable World; Nääs, I., Vendrametto, O., Mendes Reis, J., Gonçalves, R.F., Silva, M.T., von Cieminski, G., Kiritsis, D., Eds.; Springer: Berlin/Heidelberg, Germany, 2016; Volume 488, pp. 677-686.

67. Rauch, E.; Linder, C.; Dallasega, P. Anthropocentric Perspective of Production before and within Industry 4.0. Comput. Ind. Eng. 2020, 139, 105644. [CrossRef]

68. Rodrigues, V.P.; Pigosso, D.C.A.; McAloone, T.C. Process-Related Key Performance Indicators for Measuring Sustainability Performance of Ecodesign Implementation into Product Development. J. Clean. Prod. 2016, 139. [CrossRef]

69. Frey, C.B.; Osborne, M.A. The Future of Employment: How Susceptible Are Jobs to Computerisation? Technol. Forecast. Soc. 2017, 114, 254-280. [CrossRef]

70. Zhang, J.; Ding, G.; Zou, Y.; Qin, S.; Fu, J. Review of Job Shop Scheduling Research and Its New Perspectives under Industry 4.0. J. Intell. Manuf. 2019, 30, 1809-1830. [CrossRef]

71. Dalenogare, L.S.; Benitez, G.B.; Ayala, N.F.; Frank, A.G. The Expected Contribution of Industry 4.0 Technologies for Industrial Performance. Int. J. Prod. Econ. 2018, 204, 383-394. [CrossRef]

72. Fettermann, D.C.; Cavalcante, C.G.S.; de Almeida, T.D.; Tortorella, G.L. How Does Industry 4.0 Contribute to Operations Management? J. Ind. Prod. Eng. 2018, 35, 255-268. [CrossRef]

73. Kamble, S.S.; Gunasekaran, A.; Gawankar, S.A. Sustainable Industry 4.0 Framework: A Systematic Literature Review Identifying the Current Trends and Future Perspectives. Process Saf. Environ. 2018, 117, 408-425. [CrossRef] 
74. Agresti, A. Logistic regrission models using cumulative logits. In Analysis of Categorical Data, 2nd ed.; John Wiley \& Sons, Inc.: Hoboken, NJ, USA, 2010; pp. 9-43.

75. Agresti, A.; Liu, L.M. Modeling a categorical variable allowing arbitrarily many category choices. Biometrics 1999, 55, 936-943. [CrossRef] [PubMed]

76. Thomas, R.D.; Decady, Y.J. Testing for Association Using Multiple Response Survey Data: Approximate Procedures Based on the Rao-Scott Approach. Int. J. Test. 2004, 4, 43-59. [CrossRef]

77. Rauch, E.; Vickery, A.R.; Brown, C.A.; Matt, D.T. SME Requirements and Guidelines for the Design of Smart and Highly Adaptable Manufacturing Systems. In Industry 4.0 for SMEs: Challenges, Opportunities and Requirements; Matt, D.T., Modrák, V., Zsifkovits, H., Eds.; Springer: Berlin/Heidelberg, Germany, 2020; pp. 39-72.

78. Moeuf, A.; Pellerin, R.; Lamouri, S.; Tamayo-Giraldo, S.; Barbaray, R. The Industrial Management of SMEs in the Era of Industry 4.0. Int. J. Prod. Res. 2018, 56, 1118-1136. [CrossRef]

79. Eleftheriadis, R.J.; Myklebust, O. A guideline of quality steps towards zero defect manufacturing in industry. In Proceedings of the 2016 International Conference on Industrial Engineering and Operations Management, Detroit, MI, USA, 23-25 September 2016.

80. Büchi, G.; Cugno, M.; Castagnoli, R. Smart factory performance and Industry 4.0. Technol. Forecast. Soc. 2020, 150, 119790.

81. Bonekamp, L.; Sure, M. Consequences of Industry 4.0 on Human Labour and Work Organisation. J. Bus. Media Psychol. 2015, 6, 33-40.

82. Lins, T.; Rabelo Oliveira, R.A. Energy efficiency in industry 4.0 using SDN. In Proceedings of the 2017 IEEE 15th International Conference on Industrial Informatics (INDIN), Emden, Germany, 24-26 July 2017.

83. Peruzzini, M.; Gregori, F.; Luzi, A.; Mengarelli, M.; Germani, M. A social life cycle assessment methodology for smart manufacturing: The case of study of a kitchen sink. J. Ind. Inf. Integr. 2017, 7, 24-32. [CrossRef]

84. Matt, D.T.; Rauch, E.; Fraccaroli, D. Smart Factory for SMEs. ZWF 2016, 111, 52-55. [CrossRef]

85. Matt, D.T.; Rauch, E. SME 4.0: The Role of Small- and Medium-Sized Enterprises in the Digital Transformation. In Industry 4.0 for SMEs: Challenges, Opportunities and Requirements; Matt, D.T., Modrák, V., Zsifkovits, H., Eds.; Springer: Berlin/Heidelberg, Germany, 2020; pp. 3-36.

86. Horváth, D.; Szabó, R.Z. Driving Forces and Barriers of Industry 4.0: Do Multinational and Small and Medium-Sized Companies Have Equal Opportunities? Technol. Forecast. Soc. 2019, 146, 119-132.

87. Müller, J.; Voigt, K.-I. Industrie 4.0 für kleine und mittlere Unternehmen. Welche spezifischen Probleme werden bei der Einführung von Industrie 4.0 von kleinen und mittleren Unternehmen gesehen? Product. Manag. 2016, 3, 28-30.

88. Erol, S.; Jäger, A.; Hold, P.; Ott, K.; Sihn, W. Tangible Industry 4.0: A Scenario-Based Approach to Learning for the Future of Production. Procedia CIRP 2016, 54, 13-18. [CrossRef]

89. Dassisti, M.; Panetto, H.; Lezoche, M.; Merla, P.; Semeraro, C.; Giovannini, A.; Chimienti, M. Industry 4.0 paradigm: The viewpoint of the small and medium enterprises. In Proceedings of the $7 \mathrm{th}$ International Conference on Information Society and Technology, Kopaonik, Serbia, 12-15 March 2017.

90. Frank, A.G.; Dalenogare, L.S.; Ayala, N.F. Industry 4.0 Technologies: Implementation Patterns in Manufacturing Companies. Int. J. Prod. Econ. 2019, 210, 15-26. [CrossRef]

91. Luco, J.; Mestre, S.; Henry, L.; Tamayo, S.; Fontane, F. Industry 4.0 in SMEs: A Sectorial Analysis. In Advances in Production Management Systems. Production Management for the Factory of the Future, IFIP Advances in Information and Communication Technology; Ameri, F., Stecke, K.E., von Cieminski, G., Kiritsis, D., Eds.; Springer: Berlin/Heidelberg, Germany, 2019; pp. 357-365.

92. Bär, K.; Herbert-Hansen, Z.N.L.; Khalid, W. Considering Industry 4.0 Aspects in the Supply Chain for an SME. Prod. Eng. 2018, 12, 747-758. [CrossRef]

93. Dev, N.K.; Shankar, R.; Qaiser, F.H. Industry 4.0 and Circular Economy: Operational Excellence for Sustainable Reverse Supply Chain Performance. Resour. Conserv. Recy. 2020, 153, 104583. [CrossRef]

94. Jena, M.C.; Mishra, S.K.; Moharana, H.S. Application of Industry 4.0 to Enhance Sustainable Manufacturing. Environ. Prog. Sustain. Energy 2020, 39, 13360. [CrossRef]

(C) 2020 by the authors. Licensee MDPI, Basel, Switzerland. This article is an open access article distributed under the terms and conditions of the Creative Commons Attribution (CC BY) license (http://creativecommons.org/licenses/by/4.0/). 